\title{
THE POWER OF TONGUE TWISTERS STRATEGY TO INCRAESE THE STUDENTS' SPEAKING ABILITY
}

\author{
Nirwana AR ${ }^{a}$, Suraya Mukadar ${ }^{\mathrm{b}}$, \& Tri Kurnia Badu ${ }^{\mathrm{c}}$ \\ abe Universitas Iqra Buru Jl. Prof. Dr. Abd. Bassalamah, M.Si., Kab. \\ Buru, Indonesia \\ Pos-el: ${ }^{a}$ nirwana.arfin@gmail.com \\ bsurayamukadar880@gmail.com \\ 'niamine3@gmail.com
}

(Diterima: 01 Desember; Direvisi 06 Desember; Disetujui: 11 Desember 2020)

\begin{abstract}
Tongue twisters have been explored by some researchers to increase the students' speaking ability. The researcher has an opportunity to research significant effectiveness difference between tongue twisters strategy and direct interaction strategy to increase students' speaking accuracy (pronunciation) and fluency (content). A quasi-experimental design is employed with two classes of the eight graders of SMP Muhammadiyah 12 Perumnas Makassar selected purposively as the sample. The data is obtained through a pre-test and a posttest. The findings are analyzed using statistically using independent t-test procedure. Based on the post-test calculation the value of t-test is higher than the value of $t$ table, 2,04 < 3,03. According to the result, the alternative hypothesis is not rejected. It can be concluded that there is a significant effectiveness difference between students' ability to speak English who are taught by using tongue twisters strategy and those who are guided by using direct interaction strategy on post-test of speaking accuracy and fluency. Tongue twisters strategy is more effective in increasing the students' speaking ability on speaking accuracy and fluency than direct interaction strategy. Based on students' speaking products, it can be show that students understand the role of speaking. The students' speech sound is more natural.
\end{abstract}

Keywords: Speaking ability, tongue twisters strategy, direct interaction strategy

\begin{abstract}
Abstrak
Tongue twister telah dieksplorasi oleh beberapa peneliti untuk meningkatkan kemampuan berbicara siswa. Peneliti memiliki kesempatan untuk meneliti perbedaan keefektifan yang signifikan antara strategi tongue twister dan strategi direct interaction untuk meningkatkan ketepatan (pengucapan) dan kelancaran berbicara siswa (konten). Desain A quasi-experimental digunakan dengan dua kelas dari delapan kelas di SMP Muhammadiyah 12 Perumnas Makassar yang dipilih secara purposif sebagai sampel. Data diperoleh melalui pre-test dan posttest. Temuan dianalisis menggunakan statistik menggunakan prosedur uji-t independen. Berdasarkan perhitungan post-test nilai t-test lebih tinggi dari nilai t-tabel yaitu 2,04<3,03. Berdasarkan hasil tersebut, hipotesis alternatif tidak ditolak. Dapat disimpulkan bahwa terdapat perbedaan keefektifan yang signifikan antara kemampuan berbicara bahasa Inggris siswa yang diajar menggunakan strategi tongue twister dengan siswa yang dibimbing dengan menggunakan strategi direct interaction pada post-test ketepatan dan kelancaran berbicara. Strategi tongue twister lebih efektif dalam meningkatkan kemampuan berbicara siswa pada keakuratan dan kelancaran berbicara daripada strategi direct interaction. Berdasarkan kemampuan berbicara siswa, dapat ditunjukkan bahwa siswa memahami peran berbicara. Suara ucapan siswa lebih alami. Kata kunci: kemampuan berbicara, strategi tongue twister, strategi direct interaction.
\end{abstract}




\section{INTRODUCTION}

Language is an instrument for giving information, and reflecting on various things as well. Speaking is so essential in acquiring and using a language. Phonetics constitute the basics of speaking. The meaning of a word expressed by speaking can be straightforward to understand if the speaking is smooth, but if the speaking is disjointed and mispronounced, others might not understand the meaning. It is analogous to a fish out of water. It means that the information delivered cannot be understood by listeners. Pronunciation is the foundation of speaking. Proper pronunciation may make communication more natural and more relaxed and thus more successful, but poor pronunciation can never facilitate effective communication, and it can lead to a failure of communication.

In learning a foreign language, especially the English language, it must be really understood that the language sound system different from the Indonesian language. There are several sounds of the English language not found in the Indonesian language, such as vocal, consonant, diphthong, and other sound systems. Besides that, in Indonesia, language stress, length, and intonation did not influence the meaning of a word or phrase. Caused existence the different variations, the English learners often experience the difficulty caused by anything various: the varying sensitivity of ear, the matter of making unusual sounds, the distribution of the sounds, and fluency.

In English, many words can have the same pronunciation but be written differently with different meanings. For example, "to, two, and too" which all have the phonetic transcription /tu/. Sometimes, words can be written similarly but have different pronunciations as in the "ought" combinations thought, though, bough, and through. The students are indicated with the International Phonetic Alphabet and followed by examples and exercises dealing with contrasting sounds, recognition, and dictation.
In learning English, can express words, phrase, and sentences as well as, righteously pronunciation be produced by the native speaker English is the main point. It is imperative because, in language English, error pronunciation will cause the meaning of the word to be erroneous. As a consequence, the information is conveyed will not be accepted clearly.

According to information, the researchers found SMP Muhammadiyah 12 Perumnas Makassar for the class VIII, which the students were still low in speaking especially, in accuracy (pronunciation) and fluency (content). Besides that, the researchers had done observation and teaching for several days, which found some problems that students faced in speaking were accuracy (pronunciation), and fluency (content) of the students were still low. It was the same with the information from the teacher in the school. Based on the condition of the students faced in speaking, the researchers would like to solve the problems by using a strategy. The research strategy applied Tongue Twisters Strategy, so the students' speaking ability can increase.

Based on the explanation above, it was imperative to introduce the role of English speaking accuracy and pronouncing correctly toward the English learners, especially students of SMP level. Thereby, it can be expected to appear the English learners that able to master the role of speaking with pronouncing correctly in the English language, so finally, the students can talk to English accuracy and fluency. All problems above are overcome by tongue twisters strategy.

A tongue twister is a series of words or a longer piece, like a poem, constructed to be very difficult to pronounce correctly. Tongue twisters are used to create humor by challenging someone to repeat them very fast and listening to the funny results, as well as by public speakers and speechlanguage students to increase verbal agility. Tongue 
(UJSS) Vol. 1, No. 3, Bulan Tahun: 80-95

twisters are also useful in understanding how we process language. It turns out that specific sound sequences are difficult to alternate because of the changing positions in the mouth and the aural feedback of the sound similarities, and tongue twisters focus on these.

Based on the research findings there is a significant effectiveness different between students speaking ability to speak English who are taught by using tongue twisters strategy and those are taught by using direct interaction strategy. The result of the data shows that alternative hypothesis is not rejected. Using tongue twisters strategy is more effective in increasing students speaking accuracy and fluency. This finding is supported by a number researcher in previous studies have investigated the effectiveness tongue twister strategy to increase students' speaking skill. They found that tongue twisters are fun and enjoyable technique, as well as tongue twister can increase students' motivation and active in receiving the materials from the teachers. It means that tongue twisters are important and effective strategy in teaching speaking to increase the students' speaking accuracy and fluency. The novel of this study is the subject of the research and method. The method using A quasi-experimental design which is employed with two classes or two groups. This research is designed to compare the effectiveness between tongue twisters strategy as experimental group and direct interaction strategy as control group. The subject was the eight of SMP

Muhammadiyah 12 Perumnas Makassar.

\section{REVIEW OF LITERATURE}

Tongue twisters have been investigated by some researchers in teaching speaking skill and silent reading. In literature, Researchers reviewed the difference in effectiveness between tongue twisters strategy and direct interaction strategy to improve students' speaking skill.

This research decided into three themes: The effectiveness of tongue twisters strategy on students' speaking ability, the effectiveness of direct interaction strategy on students' speaking ability, and speaking skills. Researchers discussed the sections of literature about the themes below:

\subsection{The effectiveness of tongue twister strategy on students' speaking ability}

Shofiathu (2019) remarks using the tongue twister technique to improve students' pronunciation. The result of the study found that tongue twister technique can improve students' pronunciation skills and give students' positive atmosphere in English class. A teacher is recommended to find out new tongue twisters to provide chances to the students to practice their pronunciation.

Mary \& Karen (2018) have studied Segmental speech error data elicited at prosodically-defined locations in tongue twisters. The experimental design was applied in this research, and the instrument was 40 tongue-twister items. This research aimed to collect tongue twisters error data. The data showed that most of the speakers produced six repetitions, each of 40 tongue- twisters - the position of error-prone segments within two prosodic domains: intonational phrases and utterances.

Yara (2018) suggests improving students' pronunciation by using the tongue twister technique. The researcher investigated tongue twister, word stress, intonation, pronunciation. The researcher used observation checklists, field notes, and a pronunciation test as tools to collect the data. The result showed that the tongue twister technique could improve students' pronunciation. Moreover, tongue twister sentences could improve the ability to use correct word stress, the knowledge in using accurate intonation, and improve students' ability to decrease the pauses and hesitation to 
pronounce the English word. The result indicates that the students' pronunciation skills improve.

Fatchul, Rosyi, and Rizky (2017) have found tongue twister, students' pronunciation ability, and learning styles. This study aimed to investigate the effect of tongue twister technique on the pronunciation ability of students across different learning styles. The students in the experimental group were taught by using tongue twister, while those in the control group were prepared by using the repetition technique. The findings of the study showed that there was no significant difference in pronunciation ability between the groups. A tongue twister is considered beneficial by the students as they perceived that practicing tongue twisters cultivated joyful learning, and it helped them to improve their pronunciation, fluency, and motivation in learning English pronunciation. Tongue twister practice could complement the use of repetition techniques to enhance students' learning experience and learning outcomes.

Lyn and Ralph (2015) have explored Does Silent Reading Involve Articulation? Evidence from Tongue Twisters. The aim of this research is to demonstrate the effect of tongue twisters strategy to sub vocal articulation on silent reading. This study showed that tongue-twister strategy matched for syntactic complexity, syllable count, and sentential stress pattern on silent reading. A technique was developed to measure the amount of time needed for each repetition of a sentence, whether done silently or aloud. A significant difference in reading time for tongue twisters as compared to their matched controls was found for both silents as well as out-loud reading. A variety of different kinds of articulatory errors occurred in the oral repetitions, and the number of such mistakes was highly correlated with oral reading time. While mistakes could not be measured in silent reading, this correlation suggested that comparable articulatory disturbances accounted for the slower time to repeat tongue twisters silently.

Deborah, Laura, Ilene, and Charles (2014) have studied phoneme specific interference in reading: the tongue twisters effect revisited. The authors examine the tongue-twister effect (McCutchen \& Perfetti, 1982) to help determine the role of phonological information during silent reading. In the first experiment, U.S. college students took longer to judge the semantic acceptability of sentences containing several words with the same initial consonants (tongue-twisters) than of matched control sentences. Besides, when their working memory was pre-loaded with digits whose names repeated the same consonants as occurred in the sentences, a specific phonetic interference was observed. The authors conclude that tongue twisters had effects toward phonetic and the locus effected to working memory. In a second experiment employing a similar methodology but using a lexical decision task, no tongue-twister effect was found. Thus, the tongue-twister effect appears to occur during the memory and comprehension processes involved in sentence processing, not during processes involved in isolated word reading.

Katherine, Lise, and Elizabeth (2012) have studied the semantic category moderates phonological priming of proper name retrieval during tip-of-the-tongue states. This research has investigated factors that influence their resolution. The present experiment investigated whether priming effects are mitigated by semantic competition. Target questions were proper name targets (e.g., Helen Hunt, Elton John) from various grammatical categories (e.g., actor, musician). These results demonstrate that phonological overlap and semantic category such as full first name, first syllabe, same profession, and different profession had influence to the tip-of-thetongue.

Mary (2003-2012) suggests shifting from a single sound to a blend or digraph. 
(UJSS) Vol. 1, No. 3, Bulan Tahun: 80-95

Moving between $/ \mathrm{s} /$ and $/ \mathrm{sh} /$ is quite tricky, so you will find many tongue twisters that play on this sound combination: She sells seashells by the seashore. And The sixth sheik's sixth sheep's sick. In the following tongue twister, we see a shift between $/ \mathrm{k} /$ and two blends: $/ \mathrm{KR} /$ and $/ \mathrm{kl} /$ : How can a clam cram in a clean cream can?

Goldrick and Blumstein (2008: 7) assume the tongue twister paradigm induces phonological planning errors; also Ministry of Education and R \& Susiati (20019) Tongue twisters are characterized by the repetition of certain sounds and words or phrases with emphasis on pronunciation, stress, intonation, speed, and speech.

Iye Risman, (2018) states that Tongue twister is a phrase marked by alliteration that is difficult to pronounce, especially to pronounce quickly. For example, the phrase She sells seashells by the seashore is a tongue twister.

Matthew, Sheila and Blumstein (2006) have found cascading activation from phonological planning to articulatory processes: evidence from tongue twisters. The current study considers evidence from the tonguetwister paradigm to investigate such potential interactions. Acoustic analyses of various parameters of obstruents voicing in tongue twister productions show that errors induced in language twisters leave acoustic "traces" of the intended target. For example, the voice onset time of ' $k$ " fi [g] error tokens had a mean VOT that was longer than correctly produced "g" fi [g] tokens, reflecting a trace of the voiceless [k] target. Tongue twisters had impact to articulatory processes in phonological. Consistent with this account, a posthoc analysis revealed an additional influence of cascading activation from wordlevel operations; traces of the target were reduced in word outcomes relative to nonword outcomes. Finally, the extension of these analyses to a set of secondary cues to obstruent voicing showed that tongue twister production errors do not influence non-local signals.

Survey results indicated that tongue twisters are not only categorized as fun, enjoyable but also it has another contribution like motivate and stimulate the learners to be more active in receiving the materials from the teachers. It means that tongue twister can increase the students' speaking accuracy and fluency.

\subsection{Why use tongue twisters strategy}

There were some reasons for using tongue twister in language lessons:

Bulent (2011) states that tongue twister is enjoyable and fun. Tongue twister can help the students to use the intonation better and better. Besides that, it can make the English lessons very enjoyable by taking the attention of the students at once. Using tongue twister is a fun way to teach pronunciation. It is mainly an excellent technique to train sounds and increase the students' speaking ability. The students' should not focus on speed while practicing tongue twister. If they say tongue twister at a reasonable rate, they can learn the correct sound and the pronunciation correctly. Tongue twisters are one of the few types of spoken wordplay that are fun to recite and are a great tool to aid children's language development. Attempting to recite a tricky rhyme or tongue twister as fast as possible without tripping over your tongue is a great challenge - try saying,

"She sells seashells" or "Peter Piper picked a peck of pickled peppers." You cannot help but smile and enjoy the race to get it right. Tongue twisters usually rely on alliteration, the repetition of a sound starting with a similar letter with a phrase designed such that it is made very easy to slip (hence the fun).

Alex (1996-2012) states that tongue twisters are not only a linguistic fun and game but serve a practical purpose for language and speech development. For example, tongue twisters may be used by international students of English to increase their accent and speech 
pathologists often use them as a tool to help those with speech difficulties.

The verbal language was only a part of the way usually got meaning from context. In this case, tongue twister was included. Tongue twister was not exclusively categorized as fun, enjoyable. Still, also it had another contribution like motivate and stimulate the learners to be more active in receiving the materials from the teachers.

\subsection{The effectiveness of direct interaction strategy}

Direct instruction" is described as teacher-directed and fast-paced, using a highly structured presentation of antecedents and consequences (Gersten, Woodward, \& Darch, 1986: 17). This meticulously developed, highly scripted method allows constant interactions between the student and the teacher. The responsibility for student learning rests directly with the teacher's design and delivery of instruction.

Karwan, Mahta, \& Lin (2016) have investigated the role of learner-learner interaction in the development of speaking skills. A quantitative research method was employed to examine the role of learnerlearner communication in the event of speaking skills of language learners. The speaking ability of the participants was assessed before and immediately after the English course and, the questionnaire was distributed among the participants to get a more in-depth insight into the role of learnerlearner interaction in enhancing their speaking skills. The findings of the study indicated that learner-learner communication played a significant role in the classroom since students were able to improve their speaking skills in the classroom atmosphere.

Sinta (2014) investigates classroom interaction analysis in the Indonesian EFL speaking class. This study aimed at analyzing the categories of teacher talk, student talk, and classroom interaction types used during EFL speaking class. The research employed a qualitative design and applied a case study.
The data were analyzed by using FLINT (Foreign Language Interaction) system as developed by Moskowitz (1971) and types of classroom interaction of Malamah-Thomas' (1987) frameworks. The findings revealed that both teachers and students applied all categories of talk, as mentioned in the FLINT system and classroom interaction types. It is recommended for the teacher to use more categories of

'praises and encourages' to build students' confidence in speaking, 'asks questions' to promote their communicative skill, and to encourage students to use English during speaking activities, particularly in group work activities.

Valiathan (2009: 3) Direct Instruction (DI) is used to describe learning material in which the teacher or expert transmits information directly to learners structuring learning time to reach a clearly defined set of objectives as efficiently as possible.

Kouicem (2009) investigates the effect of classroom interaction, developing learner's speaking skills. The study aims to show classroom interaction can be the best pedagogical strategy to establish not only the learners' speaking skills but also to foster their capacity to generate a new language. This study is based on two questionnaires administrated to both the third year LMD students and teachers of Oral Expression to get information about the impact of classroom interaction on developing the learners' speaking skills. The analysis of the questionnaire showed that both learners and teachers consider classroom interaction as an essential pedagogical strategy in enhancing the capability of speaking.

Center on Innovation \& Improvement (2008: 1) defines Direct instruction refers to instruction led by the teacher, as in "the teacher provided direct instruction in solving these problems." Direct Instruction is an explicit, intensive instructional method that allows students of all abilities to become 
(UJSS) Vol. 1, No. 3, Bulan Tahun: 80-95

confident, capable learners. 2.4. Speaking skill

Byrne (1987: 10) states that oral communication is two ways process between the speaker and the listener involves productive skill as speaking and receptive ability is listening. Therefore, both the speaker and the listener are active during oral communication take place.

Florez (1999:11) states that Speaking is key to communication. By considering what good speakers do, what speaking tasks can be used in class, and what specific needs learners report, teachers can help learners improve their speaking and overall oral competency. Widdowson ( 1985: 85 ) suggests "an act of communication through speaking is commonly performed in face interaction and occur as part of a dialogue or instead form of verbal exchange, what is said, therefore, depends on an understanding of what case has been noted in the interaction". In this further discussion, Widdowson proposes the word "speaking" or the manifestation of language as a usage to the realization as "talking." Act of speaking involves not only the production of sound but also the use of gesture, the moment the muscle the face, and indeed the whole body.

According to Chastain (1976:334), speaking is a productive skill. As such, its development is undertaken after receptive power of listening comprehension, and perhaps reading and is always somewhat behind that receptive skill. How far the productive skill language behind and depends upon the learner and advanced in his language learning and linguistics complexity of in materials.

Speaking is a way to bring a message from one person to another to interact with them. Communication will not be running well without speaking. Speaking in term of usage is oral communication through which people express ideas or information to other people as a partner of a conversation. It means that the speaker can speak and express his/her ideas through language.

\section{The Study}

\subsection{Aims}

This study is designed to find out the effectiveness of using tongue twisters strategy to increase the students' speaking ability and the efficiency of using direct interaction strategy to increase the students' speaking ability.

Two research questions were posed to investigate these aims:

1. Is there any significant difference between the student's ability to speak English accuracy, which is taught by using tongue twisters strategy and those who are trained by using direct interaction strategy?

2. Is there any significant difference between the student's ability to speak English fluency, which is taught by using tongue twisters strategy, and those who are trained by using direct interaction strategy?

\subsection{Participants}

The participants of this research were the second year students of SMP Muhammadiyah 12 Perumnas Makassar in the academic year 2013/2014. In selecting the sample, the study used a sampling technique. This technique determined the sample based on particular considerations. Two classes are chosen for the research. The levels were $2 \mathrm{~A}$ as an experimental group and $2 \mathrm{~B}$ as a control group. The use treated the experimental group of tongue twisters strategy. Both classes are chosen as the sample with the consideration of the English teacher in the school. The types had the same level of English proficiency.

\subsection{Target Speaking}

This study was limited to the use of tongue twisters strategy and the use of direct interaction strategy to increase the students' speaking ability at the second grade of SMP Muhammadiyah 12 Perumnas Makassar, which covers accuracy (pronunciation) and 
fluency (content). The oral test was speaking performance. The study took these items because it was imperative to identify by the teacher to increase the role of tongue twisters strategy in motivating and overcoming the students' problems in speaking English.

a. Accuracy consisted of pronunciation

Pronunciation deals with the interrelated skill recognition or understanding of speaking and production of fluency language. Kinds of speech features are sound units: consonant, vowel, and Suprasegmental elements refer to stress, pitch, length intonation, and other features that always accompany the production of segmental (Ramelan, 2003: 22).

Harmer (1991: 11) states that pronunciation is how to say a word in which made of sound, stress, and intonation. Sound.

Marcel (1978: 12) states that fluency is someone's way of speaking dealing with how to procedure words in a certain period of tones without missing any main words on their speech.

\section{b. Kinds of Speaking}

Speaking was commonly divided into two types, namely speaking competency and speaking performance. In this research, the writer limited to speaking performance.

Manser M. H. (1991:306) states that performance is the person's process or manner of a play. Therefore, we may conclude that speaking performance is the way of one's behaviors in speaking with accessed their opinion with fluency and accuracy.

\section{METHOD}

This study was a quasi-experimental design. This quasi-experiment conducted in pretest; treatment consisted of six meetings and a post-test. It aimed to observe the differences increase the students' speaking ability through the use of tongue twister strategy and the use of direct interaction strategy.
Techniques of Data Analysis In this study, Both groups received a dialogues test. This test based on a lesson plan at SMP Muhammadiyah 12 Perumnas Makassar. One group was as an experimental group, and the other group was as a control group, and both groups got pre-test, treatment, and post-test. This study focuses on the nonequivalent control group design since the control group and experiment group not be close randomly.

\subsection{Research Procedures}

The data collection was analyzed through the following techniques:

\section{a. Pre Test}

The pre-test was given to the students for the first meeting, to obtain the data of the students' essential speaking ability and to ascertain that the students from both groups had the same capacity and the corresponding English proficiency before they received the treatment.

In the pre-test, the experimental group and control group received the same test. Both groups were allotted dialogues text (asking and giving help) and gave the students some minutes to practice and memorized the dialogue before a performance. Then, we picked up a team to go first. When one side finished, the next team stood up. One group conducted two students.

\section{b. Treatment}

Treatment was given to the students after doing the pre-test. In this case, the procedure was designed for six meetings for the experimental group and control group. Time allocation for each session consisted of two hours. Before the students were given treatment, the teacher gave the motivation to make the students enthusiasm and learn by providing a reward for the better speaking team.

In treatment, both groups received different treatment. The experimental group received a tongue twister strategy, and the control group received a direct interaction strategy.

1) Experimental group 
(UJSS) Vol. 1, No. 3, Bulan Tahun: 80-95

The first treatment, the Teachers gave training as one way to warm-up for stage students, rehearsals, and performances using tongue twister strategy. Begin by stretching out the muscles of the student's face and jaw. After that, warming up students' tongue by repeating short tongue twister aloud "Toy boat," "Unique New York." The next, move onto the next section was a little tricky and complicated tongue twister "red leather, yellow leather," "Good blood, bad blood," "big black bear a big black bug bit the big black bear, but the big black bear bit the big black bug" and so on. The last, teachers explained the next subject matter and then allotted a dialogue text and asked the students to focus on listening and watching the teachers read the dialogue carefully until two times. And then asked the students to repeat the conversations. The teachers revised when the students' speaking error by tongue twisters technique where the students asked to repeat the error words for three and more times until the students' speaking accuracy and fluency.

The second treatment, Tongue twisters technique, was shifted between /p/, /f/ and /v/ sounds. This treatment purpose of practicing the students' speaking ability and of knowing how the different pronounce between $/ \mathrm{p} /$, /f/ and $/ \mathrm{v} /$ sound accuracy and fluency.

Tongue twisters strategy for the third treatments was shifted between $/ \mathrm{t} /$ and $/ \mathrm{th} /$ sounds. This treatment purposed to practice the students' speaking ability and to know how different pronounce between / $\mathrm{t} /$ and $/ \mathrm{th} /$ sound accuracy and fluency.

Tongue twisters strategy for the fourth treatments was shifted between $/ \mathrm{s} /, / \mathrm{ch} /$, and $/ \mathrm{ch} /$ sounds. This treatment purposed to practice the students' speaking ability and to know how the different pronounce between $/ \mathrm{s} /, / \mathrm{ch} /$, and $/ \mathrm{ch} /$ sounds accuracy and fluency.

Tongue twister's strategy for the fifth treatment was shifted between $/ 1 /$ and $/ \mathrm{r} /$ sounds. This treatment purposed to practice the students' speaking ability and to know how different pronounce between $/ 1 /$ and $/ \mathrm{r} /$ sounds accuracy and fluency.

The sixth treatment, tongue twisters strategy was shifted between $/ \mathrm{t} /$ and $/ \mathrm{th} /$ sounds. This treatment purposed to practice the students' speaking ability and to know how the different pronounce between $/ \mathrm{t} /$ and /th/ sounds accuracy and fluency.

2) Control group

In the control group, the researchers gave task stimulus treatment, where The teachers presented (models) the task to be performed and Response-Prompt treatment, where the students completed the responsibility as the teachers' instructions. This treatment was the procedure of direct interaction strategy.

\section{c. Post-test}

The study conducted the post-test at the end of the research. It was done to measure the students' speaking ability after the treatment. It was distributed to both experimental and control groups. This intended to find out the significant differences between students' scores of both groups. The oral test on the post-test was one subject matter of treatment given. Both groups were allotted dialogues test (asking and giving help). Having one student from each group came in front of the class and asked the students to practice and memorized the dialogues. After that, the teachers asked the students back to their teams and taught their team members each other with the same strategy was given by the teachers. The teachers gave the students some minutes to practice their speaking and memorized the dialogues. Then, we picked up a team to go first. When one side finished, the next team stood up. One group conducted five students. The team with the shortest time and speaking accuracy and fluency won. The winner got a reward from the teachers, and the leader of the group got a double award from their 
members. This game helped the students to learn quickly and improve their teamwork and also gave motivation to each other.

3.6. Data Analysis

a. Analysing the students' speaking ability by using the following criteria: Scores and criteria of fluency (contain) and Accuracy (Pronounciation). Table 1

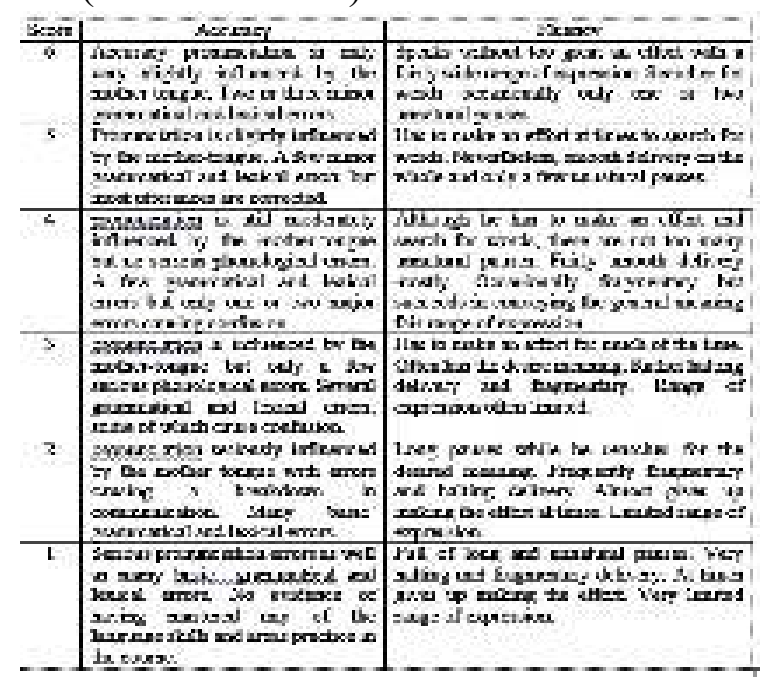

b. Classifying the students' score which fall into seven classifications:

Table 2

\begin{tabular}{|c|c|c|}
\hline No & Classification & Score \\
\hline 1 & Excellent & $9.6-10$ \\
\hline 2 & Very Good & $8.6-9.5$ \\
\hline 3 & Good & $7.6-8.5$ \\
\hline 4 & Fairly Good & $6.6-7.5$ \\
\hline 5 & Fair & $5.6-6.5$ \\
\hline 6 & Poor & $4.6-5.5$ \\
\hline
\end{tabular}

Based on the table above, the students will get excellent if their score is $9.6-10$, very good if their score is $8.6-9.5$, good if their score is $7.6-8.5$, fairly good if their score is $6.6-7.5$, fair if their score is $5.6-$ 6.5 , poor if their score is $4.6-5.5$, and very poor if their score is $0.0-4.5$.
The formula of Classifying the students' score as follows:

$X=\frac{\text { Score of criteria analysing }}{\text { Max. score of Classifying score }}$

Max. score of criteria analysing Where: $\mathrm{X}=$ Classifying the students' score.

a. Statistic Procedure

The data collected through pre-test and post-test and it was analyzed mainly through oral test statistic (mean score and standard deviation) inferential statistic (person t-test). The researchers firstly determined the level of probability of $\alpha=$ 0.05 . It means that if the probability was larger than $0.05 \quad(p>0.05)$, the null hypotheses were accepted and rejected the alternative hypotheses.

The alternative way of decision made comparing the count $t$-test with the t-table, if $\mathrm{t}$-test value was larger than $\mathrm{t}$-table, the null hypotheses was accepted and rejected the alternative hypotheses of the following statistic formula cited in Gay, R.L. (1981) would supposed to be used if only the data was calculated manually.

\section{RESULTS}

In assessing the significant difference between the test value of students' speaking ability, this study only assesses two aspects of speaking, namely fluency and accuracy. To be able to evaluate the significant difference between the variables before and after the treatment.

a. The significant difference between students' ability to speak English who are taught by using tongue twisters strategy and those who are trained by using direct interaction strategy on pretest of speaking accuracy.

Table 4.1, pre-test value in speaking accuracy determines the homogeneity of variance using the $t$-test formula. The value of T- table : 
(UJSS) Vol. 1, No. 3, Bulan Tahun: 80-95

$\alpha=0,05 d f$ for numerator $\left(d f_{1}\right)=35-$

$1=34 d f$ for denominator $\left(d f_{2}\right)=35-$

$1=34$

In the $\mathrm{T}-$ table for $\alpha=0,05 \mathrm{df} 1=34$ $\mathrm{df} 2=34$ (within 30), $\mathrm{T}$ - table is 2,04 (see table 4.1). Based on the calculation, the value of the t-test is smaller than the value of t-table, $0,34<2,04$. It means that in speaking accuracy for both groups between class VIII $\mathrm{A}$ as experiment group and class VIII B as a control group of SMP Muhammdiyah 12 Perumnas Makassar, there is no significant difference between the data of the two groups. According to the result, it can be concluded that the alternative hypothesis is not rejected, which means two groups are homogenous, and the t-test can be continued. The data show that the students from both groups have the same capacity and the corresponding English proficiency in speaking accuracy.

\section{Tabel 4.1}

Analysis result on pre-test of speaking accuracy

\begin{tabular}{lll}
\hline Variable & $\begin{array}{l}\text { T-tests } \\
\text { Value }\end{array}$ & T-table Value
\end{tabular}

$\begin{array}{lll}\mathrm{X}_{1}-\mathrm{X}_{2} & 0,34 \quad 2,04\end{array}$

a. The significant difference between students' ability to speak English who are taught by using tongue twisters strategy and those who are trained by using direct interaction strategy on pre-test of speaking fluency.

The pre-test was aimed to discover the equity of the two groups before administering treatments by using t-test procedure. It was conducted on 9th February 2012 to Class VIII $\mathrm{A}$ and Class VIII $\mathrm{B}$ of

SMP Muhammadiyah 12 Perumnas Makassar. The pre-test involved 70 students divided into two classes. Class VIII A is an experimental group consists of 35 students, and VIII-A is as control group consists of 35 students. The scoring of the students' speaking was adapted from tongue twisters strategy and direct interaction strategy. Pre- test gave to the students for the first meeting, to know the students' ability before the application of tongue twisters strategy and direct interaction strategy in speaking English. In the pre-test, the students allotted dialogues text and gave the students some minutes to practice their speaking and memorized the dialogue before the performance. Then, we picked up a team to go first. When one team finishes, the next team stand up. One group conducted two students. The teachers observed what the students' speaking error. Then, we gave a sign on the paper what the students' speaking error on the dialogue text-based the scoring rubric of oral test. This test was purposed to obtain the data of the students' essential speaking ability and to ascertain that the students from both groups had the same capacity and the corresponding English proficiency before they received the treatment. The next step is determining the homogeneity of variance using the t-test formula. Pre-test value in speaking accuracy below:

Tabel 2

Analysis result on pre-test of speaking fluency

\begin{tabular}{lll}
\hline Variable & $\begin{array}{l}\text { T-tests } \\
\text { Value }\end{array}$ & $\mathbf{T}$-table Value \\
\hline $\mathrm{X}_{1}-\mathrm{X}_{2}$ & 0,58 & 2,04 \\
\hline
\end{tabular}

The value of T- table :

$\alpha=0,05 d f$ for numerator $\left(d f_{1}\right)=$ $35-1=34$

$d f$ for denominator $\left(d f_{2}\right)=35-1=34$

In the $\mathrm{T}-$ table for $\alpha=0,05 \mathrm{df} 1=34 \mathrm{df} 2=$ 34 (within 30), $\mathrm{T}$ - table is 2,04 (see table 4.1). Based on the calculation, the value of the $t-$ test was smaller than the value of ttable, 0,58 $<2,04$. It means that in speaking accuracy for both groups between class VIII A as experiment group and class VIII B as a control group of SMP Muhammdiyah 12 Perumnas Makassar, there is no significant difference between the data of the two groups. 
According to the result, it can be concluded that the alternative hypothesis is not rejected, which means two groups are homogenous, and the t-test can be continued.

c. The significant difference between students' ability to speak English who are taught by using tongue twisters strategy and those who are motivated by using direct interaction strategy on post-test of speaking accuracy.

The students were given a post-test after treatment. Treatment was given for the experiment group by using the tongue twisters strategy and control group by using direct interaction strategy. The researcher took six times meetings. Each meeting runs 30 until 40 minutes. Each student got 3-4 minutes to practice dialogues text that they would getlesson plain of experimental class and control class.

The post-test was administered on April 13th, 2013 to control group and experimental group. Both groups were given an oral test based on a dialogue text. Divide small groups - two members for one group. The researchers allotted a dialogue text and gave the students some minutes to practice their speaking and memorized the dialogue before a performance. Then, we picked up a team to go first. When one team finishes, the next team stand up, the teacher recorded their voices with using the voice recorder on a mobile phone to measure the students' speaking ability accuracy as data collection and observed what the students' speaking error. Then, we gave a sign on the paper what the students' speaking errors on the dialogue text. After arriving at home, The researchers did a revision data collection based on the scoring rubric of the oral test. The dialogue text is one subject matter of treatment.

The next step to finding out is there any significant difference between the student's ability to speak English who are taught by using tongue twisters strategy and those who are trained by using direct interaction strategy in speaking accuracy by calculating the value of the T-test. Post-test cost in speaking skill below:

Tabel 3. Analysis result on post-test of speaking accuracy

\begin{tabular}{llc}
\hline Variable & $\begin{array}{l}\text { T-tests } \\
\text { Value }\end{array}$ & T - table Value \\
\hline $\mathrm{X}_{1}-\mathrm{X}_{2}$ & 3,03 & 2,04 \\
\hline \multicolumn{3}{c}{ Sumber: Gay $(1981)$}
\end{tabular}

The value of T- table :

$\alpha=0,05 d f$ for numerator $\left(d f_{1}\right)=35-1=34$ $d f$ for denominator $\left(d f_{2}\right)=35-1=34$ In the $\mathrm{T}$ - table (see Table 3) for $\alpha=0,05 \mathrm{df1}=34$ $\mathrm{df} 2=34$ (within 30), $\mathrm{T}$ - table is 2,04. Based on the calculation, the value of the t-test was higher than the value of t-table, $2,04<3,03$. It means that in speaking fluency for both groups between class VIII A as experiment group and class VIII B as a control group of SMP Muhammdiyah 12 Perumnas Makassar, there is a significant difference between students ability to speak English who are taught by using tongue twisters strategy and those who are taught by using direct interaction strategy. According to the result, it can be concluded that the alternative hypothesis is not rejected.

d. The significant difference between students' ability to speak English who are taught by using tongue twisters strategy and those who are motivated by using direct interaction strategy on post-test of speaking fluency.

The students were given a post-test after treatment. Treatment was given for the experiment group by using the tongue twisters strategy and control group by using direct interaction strategy. The researchers took six times meetings. Each meeting runs 30 until 40 minutes. Each student got 3-4 minutes to practice dialogues text that they would getlesson plain of experimental class and control class.

The post-test was administered on April 13th, 2013 to control group and experimental 
(UJSS) Vol. 1, No. 3, Bulan Tahun: 80-95

group. Both groups were given an oral test based on a dialogue text. Divide small groups - two members for one group. The researchers allotted a dialogue text and gave the students some minutes to practice their speaking and memorized the dialogue before the performance. Then, we picked up a team to go first. When one team finishes, the next team stand up, the teachers recorded their voices with using the voice recorder on a mobile phone to measure the students' speaking ability fluency as data collection and observed what the students' speaking error. Then, we gave a sign on the paper what the students' speaking errors on the dialogue text. After arriving at home, We did a revision data collection based on the scoring rubric of the oral test. The dialogue text was one subject matter on treatment.

The next step finds out there is any significant difference between the student's ability to speak English who are taught by using tongue twisters strategy and those who are trained by using direct interaction strategy by calculating the value of the Ttest. Post-test value in speaking fluency below:

Tabel 4. Analysis result on post-test of speaking fluency

\begin{tabular}{rrl}
\hline Variable & $\begin{array}{l}\text { T-tests } \\
\text { Value }\end{array}$ & $\begin{array}{l}\text { T-table } \\
\text { Value }\end{array}$ \\
\hline $\mathrm{X}_{1}-\mathrm{X}_{2}$ & 0,39 & 2,04 \\
\hline
\end{tabular}

Sumber: Gay (1981)

The value of $\mathrm{T}$ - table :

$\alpha=0,05$

$d f$ for numerator $\left(d f_{1}\right) \quad=35-1=34$ $d f$ for denominator $\left(d f_{2}\right)=35-1=34$

In the $\mathrm{T}-$ table for $\alpha=0,05 \mathrm{df} 1=34$ $\mathrm{df} 2=34$ (within 30), $\mathrm{T}-$ table is 2,042 . Based on the calculation, the value of the ttest was higher than the value of t-table, $2,04<3,39$. It means that in speaking fluency for both groups between class VIII $\mathrm{A}$ as experiment group and class VIII B as a control group of SMP Muhammdiyah 12 Perumnas Makassar, there is a significant difference between students ability to speak English who are taught by using tongue twisters strategy and those who are taught by using direct interaction strategy. According to the result, it can be concluded that the alternative hypothesis is not rejected.

This research was aimed to find out is there any significant difference between the student's ability to speak English who were taught by using tongue twisters strategy and those who were trained by using direct interaction strategy in speaking accuracy and fluency.

a. The significant difference between students' ability to speak English who are taught by using tongue twisters strategy and those who are trained by using direct interaction strategy on pretest of speaking accuracy.

The speaking accuracy test on oral tests in the pretest is used as the instrument in this study for the experiment group and control group. Furthermore, the t-test value and t-table value formula are used to compute the pretest score. Besides, the students' pretest data are analyzed to know the initial students' speaking ability on oral tests in speaking accuracy and to measure the equity between the experimental and control group before the treatment. The $\mathrm{t}$ test value on a pretest in speaking skill indicated that there was no significant difference between the students' speaking accuracy score of experimental and control groups because the students' speaking accuracy value of t-tests $(0,34)$ is smaller than the cost of $t$ - table $(2,04)$. It means the null hypothesis was not rejected that the students' speaking ability in speaking accuracy oral test before treatment between both groups was equal.

b. The significant difference between students' ability to speak English who 
are taught by using tongue twisters strategy and those who are trained by using direct interaction strategy on pretest of speaking fluency.

The speaking fluency test on oral tests in the pretest is used as the instrument in this study for the experiment group and control group. Furthermore, the t-test value and $\mathrm{t}$ table value formula are used to compute the pretest score. Besides, the students' pretest data are analyzed to know the initial students' speaking ability on oral tests in speaking fluency and to measure the equity between the experimental and control group before the treatment. The t-test value on a pretest in speaking fluency indicated that there was no significant difference between the students' speaking accuracy score of experimental and control groups because the students' speaking fluency value of t-tests $(0,58)$ is smaller than the amount of $t$ - table $(2,04)$. It means the null hypothesis was not rejected that the students' speaking ability in speaking fluency oral test before treatment between both groups was equal.

a. The significant difference between students' ability to speak English who are taught by using tongue twisters strategy and those who are trained by using direct interaction strategy on posttest of speaking accuracy.

Having received some treatments, the post-test was administered to the experimental and control groups. This test was intended to measure whether tongue twisters strategy and direct interaction strategy can help students increase their speaking ability. The post-test computation result showed that the findings might be concluded that in speaking, assessment on accuracy has increased dramatically. The students' speaking accuracy of the t-test value $(3,03)$ is bigger than the cost of t table $(2,042)$. Thus, the alternative hypothesis was not rejected, which means that there were significant differences between the experimental and control groups' scores after treatment. From the explanation above, it can be concluded that the students who received the procedure by using tongue twisters strategy have significant improvement, mainly in accuracy. The students who received tongue twister strategy have utterances and mother tongue.

b. The significant difference between students ability to speak English who are taught by using tongue twisters strategy and those who are trained by using direct interaction strategy on posttest of speaking fluency Having received some treatments, the posttest was administered to the experimental group and control group. This test was intended to measure whether tongue twisters strategy and direct interaction strategy can help students increase their speaking ability. The post-test computation result showed that the findings concluded that in speaking, assessment on accuracy and fluency have a significant increase. The students' speaking fluency of t-test value $(3,39)$ is bigger than the cost of $t$ table $(2,04)$. Thus, the alternative hypothesis was not rejected, which means that there were significant differences between the experimental group and control group scores after treatment. From the explanation above, it can be concluded that the students who received the procedure by using tongue twisters strategy have a significant increase in speaking accuracy and fluency.

\section{CONCLUSION}

Tongue twisters strategy is a great assessment tool for students to use correct pronunciation and to help students grasp intricate sounds. Tongue twisters strategy can reinforce the students' vocabulary and gives them an enjoyable way to develop their pronunciation skills while increasing vocabulary. Tongue twisters are not sufficiently competent to improve students' 
(UJSS) Vol. 1, No. 3, Bulan Tahun: 80-95

speaking ability. Students need to memorize many vocabulary and practice students' speaking every time. Tongue twisters only help the students' tongue to be more flexible to speak English accurately and fluently.

In assessing the significant difference between the test value of students' speaking ability, the conclusion was taken by research questions.

1. Is there any significant difference between the student's ability to speak English accuracy, which is taught by using tongue twisters strategy, and those who are trained by using Direct

Interaction Strategy?

Based on the calculation, the value of the t-test is higher than the cost of t-table, 2,04 $<3,03$. .

According to the result, it can be concluded that the alternative hypothesis is not rejected. Based on students' speaking products, it can be show that There is any significant different between students' speaking ability in English accuracy who are taught by using tongue twisters strategy than students who are taught by using direct interaction strategy.

2. Is there any significant difference between the student's ability to speak English fluency, which is taught by using tongue twisters strategy, and those who are trained by using Direct Interaction Strategy?

Based on the calculation, the value of the t-test was higher than the cost of t-table, $2,04<3,39$. It means that in speaking fluency for both groups between class VIII A as experiment group and class VIII B as a control group of SMP Muhammdiyah 12 Perumnas Makassar, there is a significant difference between students ability to speak English who are taught by using tongue twisters strategy and those who are trained by using direct interaction strategy.
According to the result, it can be concluded that the alternative hypothesis is not rejected.

There are some factors influencing students' speaking results when using tongue twisters strategy in teaching speaking oral test. The first one tongue twisters are not only categorized as fun, enjoyable but also it has another contribution like motivate and stimulate the students to be more active in receiving the materials from the teacher. Based on the treatment given, tongue twisters strategy can arouse students' interest and motivation. Thus, students can understand the content easily. By wellpreparation in utilizing, it could assist students in speaking English with pronunciation fluency and accuracy and good oral test.

\section{REFERENCES}

Alex, B. (1996-2012). Retrieved from http://www.kindspot.com.au/schoolzo ne/ Speech Tongue Twister $+4108+308+$ article.htm. (August 27th, 2012)

Alicia Howe, eHoe Contributor, 2012. http://www.ehow.com/list_5951101_e sl-tongue-twistergames.html\# ixzz22U3qtsUg. [August 27th, 2012]

Bennett, R., \& Bennett, S. T. (1991). free activities you can do with your child. Holbrook, MA: Bob Adams

Bin-Tahir, S. Z., Atmowardoyo, H., Dollah, S., \& Rinantanti, Y. (2017). Multilingual Instructional Model of Pesantren Schools in Indonesia. Journal of Language Teaching and Research, 8(6), 1210-1216. Byrne, Donn. 1987. Teaching Oral English.

Singapore. Longman Singapore Publisher

Sam, B., Iye, R., Ohoibor, M., Umanailo, M. C. B., Rusdi, M., Rahman, A. B. D., \& Hajar, I. (2019). Female Feminism in 
(Nirwana AR, Suraya Mukadar, Tri Kurnia Badu)

the Customary Island of Buru. Int. J. Sci. Technol. Res, 8(8), 1877-1880.

Bin-Tahir, S. Z., Hanapi Hanapi, I. H., \& Suriaman, A. (2020). Avoiding Maluku Local Languages Death Through Embedded Multilingual Learning Model: Menghindari Kematian Bahasa Daerah Maluku melalui Model Pembelajaran Embedded Multilingual. Uniqbu Journal of Social Sciences, 1(1), 5360.

Bin-Tahir, S. Z., Hanapi Hanapi, I. H., \& Suriaman, A. (2020). Avoiding Maluku Local Languages Death Through Embedded Multilingual Learning Model: Menghindari Kematian Bahasa Daerah Maluku melalui Model Pembelajaran Embedded Multilingual. Uniqbu Journal of Social Sciences, 1(1), 5360.

Hajar, I., Ternate, K., Mukadar, S., Nirwana, A. R., \& Badu, T. K. (2020). Learning Style Of An Outstanding Student In English Learning At SMA Negeri 1 Buru:(Gaya Belajar Bahasa Inggris Siswa Berprestasi di SMA Negeri 1 Buru). Uniqbu Journal of Social Sciences, 1(2), 78-85.

Hajar, I., Rahman, A., Tenriawali, A. Y., \& Mangesa, R. (2020). THE INFLUENCE OF PODCASTS IN LEARNING ENGLISH VOCABULARY OF TWELVE GRADE STUDENTS OF SMA NEGERI 2 BURU. EXPOSURE: JURNAL PENDIDIKAN BAHASA INGGRIS, 9(2), 235-249.

Rahman, A., \& Hajar, I. (2020). The Effect of Audiobook on Reading Comprehension of the Eleventh Grade Students of SMA Negeri 2 Buru. ELT WORLDWIDE, 7(2), 104-115.

Sitompul, Hamela S., et al. "Penerapan Model Pembelajaran Sinektikuntuk Meningkatkan Hasil Belajar Peserta
Didik Pada Pokok Bahasan Kologatif Larutan : (Application of Synectic Learning Models to Improve Students' Learning Achievement in Solution Colligative Discussion)." Uniqbu Journal of Exact Sciences, vol. 1, no. 2, 2020, pp. 52-58, doi:10.47323/ujes.v1i2.45

Tenriawali, A. Y. (2018). Representasi korban kekerasan dalam teks berita daring tribun timur: analisis wacana kritis [the representation victims of violence in tribun timur online news text: critical discourse analysis]. TOTOBUANG, 6 (1), 1, 15. Hajar, I., Ternate, K., Mukadar, S., Nirwana, A. R., \& Badu, T. K. (2020). Learning Style Of An Outstanding Student In English Learning At SMA Negeri 1 Buru:(Gaya Belajar Bahasa Inggris Siswa Berprestasi di SMA Negeri 1 Buru). Uniqbu Journal of Social Sciences, 1(2), 78-85.

Wael, A., Tinggapy, H., Rumata, A. R., Tenriawali, A. Y., Hajar, I., \& Umanailo, M. C. B. (2021). REPRESENTASI PENDIDIKAN KARAKTER DALAM DAKWAH ISLAM DI MEDIA SOSIAL. Academy of Education Journal, 12(1), 98-113. https://doi.org/10.47200/aoej.v12i1.42 $\underline{8}$

Sumiaty, S., Kaharuddin, K., Tenriawali, A. Y., \& Hajar, I. (2020). PENGUNGKAPAN CIRI PRIBADI MELALUI GAYA BAHASA PADA NOVEL HEKSALOGI SUPERNOVA KARYA DEWI LESTARI: KAJIAN STILISTIKA: (Disclosure of Personal Characters through Language Styles in Dewi Lestari's Supernova Hexalogy Novel: Stilistics Study). Uniqbu Journal of Social Sciences, 1(3), 113-123. https://doi.org/10.47323/ujss.v1i3.72 
(UJSS) Vol. 1, No. 3, Bulan Tahun: 80-95

Hajar, I., Rahman, A., Tenriawali, A. Y., \& Mangesa, R. (2020). THE INFLUENCE OF PODCASTS IN LEARNING ENGLISH VOCABULARY OF TWELVE GRADE STUDENTS OF SMA NEGERI 2 BURU. EXPOSURE: JURNAL PENDIDIKAN BAHASA INGGRIS, 9(2), 235-249.

$\backslash$ Bin-Tahir, S. Z., Saidah, U., Mufidah, N., \& Bugis, R. (2018). The impact of translanguaging approach on teaching Arabic reading in a multilingual classroom. Ijaz Arabi Journal of Arabic Learning, 1(1).

Sam, B., Iye, R., Ohoibor, M., Umanailo, M. C. B., Rusdi, M., Rahman, A. B. D., \& Hajar, I. (2019). Female Feminism in the Customary Island of Buru. Int. J. Sci. Technol. Res, 8(8), 1877-1880.

Bin-Tahir, S. Z., Hanapi Hanapi, I. H., \& Suriaman, A. (2020). Avoiding Maluku Local Languages Death Through Embedded Multilingual Learning Model: Menghindari Kematian Bahasa Daerah Maluku melalui Model Pembelajaran Embedded Multilingual. Uniqbu Journal of Social Sciences, 1(1), 5360 .

Hajar, I., Salija, K., \& Muliati, A. (2019). THE INTERFERENCE OF INDONESIAN ON THE STUDENTS'ENGLISH WRITING OF MUHAMMADIYAH UNIVERSITY OF MAKASSAR (Doctoral dissertation, Doctoral dissertation, UNIVERSITAS NEGERI MAKASSAR).

Hajar, I., Ternate, K., Mukadar, S., Nirwana, A. R., \& Badu, T. K. (2020). Learning Style Of An Outstanding Student In
English Learning At SMA Negeri 1 Buru:(Gaya Belajar Bahasa Inggris Siswa Berprestasi di SMA Negeri 1 Buru). Uniqbu Journal of Social Sciences, 1(2), 78-85.

Hajar, I., Rahman, A., Tenriawali, A. Y., \& Mangesa, R. (2020). THE INFLUENCE OF PODCASTS IN LEARNING ENGLISH VOCABULARY OF TWELVE GRADE STUDENTS OF SMA NEGERI 2 BURU. EXPOSURE: JURNAL PENDIDIKAN BAHASA INGGRIS, 9(2), 235-249.

Rahman, A., \& Hajar, I. (2020). The Effect of Audiobook on Reading Comprehension of the Eleventh Grade Students of SMA Negeri 2 Buru. ELT WORLDWIDE, 7(2), 104-115.

Sitompul, Hamela S., et al. "Penerapan Model Pembelajaran Sinektikuntuk Meningkatkan Hasil Belajar Peserta Didik Pada Pokok Bahasan Kologatif Larutan : (Application of Synectic Learning Models to Improve Students' Learning Achievement in Solution Colligative Discussion)." Uniqbu Journal of Exact Sciences, vol. 1, no. 2, 2020, pp. 52-58, doi:10.47323/ujes.v1i2.45.

Tenriawali, A. Y. (2018). Representasi korban kekerasan dalam teks berita daring tribun timur: analisis wacana kritis [the representation victims of violence in tribun timur online news text: critical discourse analysis]. TOTOBUANG, 6 (1), 1, 15.

Iye, R., Tenriawali, A. Y., Susiati, A., \& Buton, D. (2020). Makna dan Fungsi Emosi Mahasiswa Kota Baubau dalam Ranah Demonstrasi: The Meaning 
(Nirwana AR, Suraya Mukadar, Tri Kurnia Badu)

And Emotional Function Of Students Of Baubau City In The Demonstration Plan. Uniqbu Journal of Social Sciences, 1(1), 25-37.

Yusdianti, A. (2020). THE REPRESENTATION VICTIMS OF VIOLENCE IN TRIBUN TIMUR ONLINE NEWS TEXT: CRITICAL DISCOURSE ANALYSIS.

Susiati, S., Masniati, A., Tuasalamony, K., Hatuwe, R. S. M., Tahir, S. Z. B., Tenriawali, A. Y., \& Marasabessy, R. N. (2020). MEMBANGUN KETAHANAN RELEGIUS ANAK MELALUI ACTIVE PARENTAL INVOLVEMENT. Jurnal Islam Nusantara, 4(1), 111-125.

Rahman, A., Atmowardoyo, H., \& Salija, K. (2018). Podcast Effects on EFL Learners' Listening Comprehension. ELT WORLDWIDE, 5(2), 151-164.

Tuharea, V. U., Bin Tahir, S. Z., Ami, I. S. O., \& Rahman, A. (2020). Buru Language Conservation Through Sustainable Mulok Learning In Buru Regency:(Konservasi Bahasa Buru melalui Pembelajaran Mulok Berkelanjutan di Kabupaten Buru). Uniqbu Journal of Social Sciences, $1(2), 49-55$.

Yusuf, S., Umanailo, M. C. B., \& Nirwana, A. R. (2020). RELASI KEPALA DESA DAN BADAN PERWAKILAN DESA DALAM PEMANFAATAN DANA DESA DI KECAMATAN NAMLEA. Sosioglobal: Jurnal Pemikiran dan Penelitian Sosiologi, 4(2), 130-140.

Nirwana, A. R., \& Nirwana, A. R. (2018). Effects of Writing Corrective Feedback onStudents' Linguistic Error
(Doctoral dissertation, Doctoral dissertation, UNIVERSITAS NEGERI MAKASSAR).

Mukadar, S., \& Budiono, B. (2020). Analisis Pemerataan Pendidikan Tingkat Pendidikan Dasar Di Kabupaten Buru Provinsi Maluku. Jurnal Kebijakan dan Pengembangan Pendidikan, 7(2).

Musyawir, M., \& Loilatu, S. H. (2020). Kemampuan Menulis Karangan Narasi Berdasarkan Pengalaman Pribadi Siswa:(the Ability to Write a Narrative Essay Based on Students' Personal Experiences). Uniqbu Journal of Social Sciences, 1(2), 1-12.

Loilatu, S. H., Rusdi, M., \& Musyowir, M. (2020). Penerapan Sistem Informasi Manajemen Pendidikan dalam Proses Pembelajaran. Jurnal Basicedu, 4(4), 1408-1422.

Malmia, Wa, et al. "Efektifitas Pembelajaran Contextual Teaching and Learning (Ctl) Terhadap Hasil Belajar Matematika Siswa : (the Effectiveness of Contextual Teaching and Learning (Ctl) on Student Mathematics Learning Achievements)." Uniqbu Journal of Exact Sciences, vol. 1, no. 2, 2020, pp. 31-39, doi:10.47323/ujes.v1i2.26.

Badu, Tri K., and Muh S. Ikbal. "Perbedaan Pemahaman Konsep Fisika Siswa Melalui Model Problem-based Learning Dan Pembelajaran Interaktif: (Differences in Students' Understanding of Physics Concepts Through the Problem-based Learning Model and Concept-based Interactive Learning)." Uniqbu Journal of Exact Sciences, vol. 1, no. 2, 2020, pp. 2330, doi:10.47323/ujes.v1i2.27.

Bin Tahir, S. Z. (2015). Multilingual behavior of Pesantren IMMIM students in Makassar. Asian EFL Journal, 86, 45-64.

Bin-Tahir, S. Z., Saidah, U., Mufidah, N., \& Bugis, R. (2018). The impact of 
(UJSS) Vol. 1, No. 3, Bulan Tahun: 80-95

translanguaging approach on teaching Arabic reading in a multilingual classroom. Ijaz Arabi Journal of Arabic Learning, 1(1).

Bin Tahir, S. Z. (2015). The attitude of Santri and Ustadz toward multilingual education at Pesantren. International Journal of Language and Linguistics, 3(4), 210-216.
Saidah, U., Bin-Tahir, S. Z., \& Mufidah, N. (2018). ARABIC TEACHERS'COMPETENCE: A CASE OF MADRASAH SCHOOLS IN MALUKU. Ijaz Arabi Journal of Arabic Learning, 1(2). 